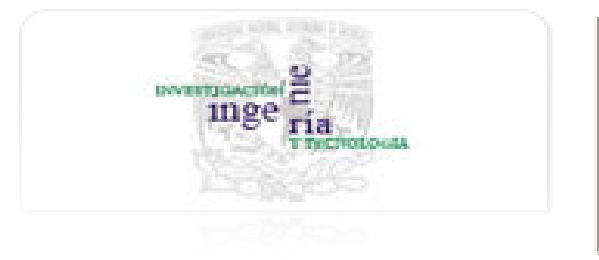

Ingeniería. Investigación y Tecnología ISSN: $1405-7743$

iit.revista@gmail.com

Universidad Nacional Autónoma de México

México

Escalante-Sandoval, C.A.

Mixed Distributions in Low-Flow Frequency Analysis

Ingeniería. Investigación y Tecnología, vol. X, núm. 3, julio-septiembre, 2009, pp. 247-252

Universidad Nacional Autónoma de México

Distrito Federal, México

Available in: http://www.redalyc.org/articulo.oa?id=40411490007

How to cite

Complete issue

- More information about this article

Journal's homepage in redalyc.org

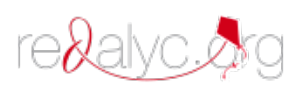

Scientific Information System Network of Scientific Journals from Latin America, the Caribbean, Spain and Portugal Non-profit academic project, developed under the open access initiative 
RIIT Vol.X. Núm.3. 2009 247-253, ISSN 1405-7743 FI-UNAM

(artículo arbitrado)

\title{
Mixed Distributions in Low-Flow Frequency Analysis
}

\section{Distribuciones mezcladas en el análisis de frecuencias de flujos minimos}

\author{
C.A. Escalante-Sandoval \\ División de Ingenierías Civil y Geomática. \\ Facultad de Ingeniería, UNAM. México. \\ E-mail:caes@servidor.unam.mx
}

(Recibido: septiembre de 2007; aceptado: mayo de 2008)

\begin{abstract}
Low-flow characteristics are required to solve several water-engineering problems. In this paper, the Mixed Gumbel and the Two Component Extreme Value distributions are presented toward their applications in low-flow frequency analysis. A region in southern Mexico, with 39 gauging stations was selected to analyze the lowest 1 day flows. Additionally, in order to calculate the stream design flow ( $\left.{ }_{7} \mathrm{Q}_{10}\right)$ for water quality standards downstream of the Hydroelectric project La Parota, the lowest 7 day average flows were used. Results produced by fitting the mixed distribution were compared with those obtained by the Weibull-3, Gumbel, Lognormal-3 and General Extreme Value distributions. Results suggest that mixed distributions are a suitable option to be considered when analyzing minimum flows.
\end{abstract}

Keywords: Minimum flow frequency analysis, maximum likelihood, heterogeneoussamples, waterquality.

\section{Resumen}

En muchos de los problemas de ingeniería del agua se requiere conocer las características de los flujos mínimos. En el artículo se presenta la aplicación de las distribuciones Gumbel Mixta y de Valores Extremos de Dos Componentes en el análisis de frecuencias de gastos mínimos. Una región localizada en el sureste de México, con un total de 39 estaciones de aforos, fue seleccionada para analizar los gastos minimos anuales con duración de un día. Adicionalmente se utilizaron los gastos mínimos anuales promedio de siete dias consecutivos con el fin de obtener el gasto de diseño $\left.{ }_{7} Q_{10}\right)$ para cumplir con los estándares de calidad hídrica aguas abajo del proyecto hidroeléctrico La Parota. Los eventos estimados por las distribuciones mezcladas fueron comparados con aquellos obtenidos por las distribuciones Weibull-3, Gumbel, Lognormal-3 y General de Valores Extremos. Los resultados sugieren que las distribuciones mezcladas son una opción adecuada a ser considerada en el análisis de flujos mínimos.

Desciptores: Análisis de frecuencias de flujos mínimos, máxima verosimilitud, muestras heterogéneas, calidad del agua.

\section{Introduction}

Low-flow is the flow of water in a stream during prolonged dry weather. By contrast, a drought is a natural event that results from an extended period of below average precipitation. While droughts include low-flows, a continuous seasonal low-flow event is not necessarily a drought. A summary about the status of low-flow hydrology can be found in Smakhtin (2001) and Pyrce (2004).

Quantiles of annual low-flow are commonly used as design flows on which to base the design of 
structures such as wastewater-treatment plants or for describing the capability of a stream to supply requirements for the regulation of fluvial transport, water supply, hydropower, liquid waste disposal, irrigation systems, or assessing the impact of prolonged droughts on aquatic ecosystems.

For instance, when assessing the suitable conditions for aquatic life, a hydrologically-based design flow (EPA, 2006) is computed using the single lowest flow event from each year of record and then examining these flows for a series of years. When a sufficiently long discharge record is available at a river site, low-flow statistics, such as the lowest 7 day average flow that occurs on average once every 10 years $\left({ }_{7} \mathrm{Q}_{10}\right)$, can be obtained through the use of probability distributions. By contrast, the biologically-based design flows (EPA, 2006) use durations and frequencies specified in water quality criteria for individual pollutants and whole effluents; they can be based on the available biological, ecological and toxicological information concerning the stresses that aquatic organisms, ecosystems, and their uses can tolerate.

This method is empirical, not statistical, because it deals with the actual flow record itself, not with a statistical distribution intended to describe the flow record. The biologically-based definition also recognizes that drought imposes severe stress on aquatic organisms, whether pollutants are present or not.

Low-flows typically aggravate the effects of water pollution. During a low flow event, there is less water available to dilute effluent loadings, resulting in higher in-stream concentration of pollutants. Aquatic life criteria are expressed in terms of the intensity of concentration, duration of averaging period, and average frequency of allowed excursions, which are defined as any flow lower than the design flow. Two concentrations, a continuous (CC) and a maximum (MC) are used to protect aquatic life from chronic and acute effects, respectively. From a hydrological point of view, EPA (2006) recommends the use of the ${ }_{1} \mathrm{Q}_{10}$ flow as the design flow for the $\mathrm{MC}$ and the ${ }_{7} \mathrm{Q}_{10}$ as the design flow for the CC.

Extensive literature is available on the application of probability distributions for prediction of flood frequencies, while the number of studies reported on frequency of low flow is rather limited. The modest interest in finding the most appropriate distribution of low flow is due to the relatively short return periods used in low flow design (less than 50 years).

Gumbel (1958) discussed the use of the 3-parameter Weibull distribution (W3) for fitting low flows:

$$
\begin{aligned}
& f(x)=[\alpha / \beta][(x-\gamma) / \beta]^{\alpha-1} \exp \left\{-[(x-\gamma) / \beta]^{\alpha}\right\}, \\
& x \geq 0 ; \alpha>0 ; \beta>0 ;-\infty<\gamma<\infty,
\end{aligned}
$$

where $\alpha, \beta$ and $\gamma$ are the shape, scale and location parameters.

The Gumbel distribution (EV1) is commonly used for low flow frequency analysis (Al-Mashidani et al., 1980):

$$
\begin{aligned}
& f(x)=(1 / \alpha) \exp \{-[(\omega-x) / \alpha]\} \\
& \exp \langle-\exp \{-[(\omega-x) / \alpha]\}\rangle,
\end{aligned}
$$

where $\omega$ and $\alpha$ are the location and scale parameters.

This distribution is not bounded in the lower or upper tail. The smallest values of the EV1 distribution have a high probability of negative values.

Chow (1964) provided a theoretical justification for the use of the 3-parameter Lognormal distribution (LN3) in low flow analysis:

$$
f(x)=\frac{1}{\left(x-x_{0}\right) \sigma_{y} \sqrt{2 \pi}} \exp \left\{-\frac{\left[\ln \left(x-x_{0}\right)-\mu_{y}\right]^{2}}{2 \sigma_{y}^{2}}\right\},
$$

where $x_{0}, \mu_{y}$ and $\sigma_{y}$ are the location, scale and shape parameters. This distribution is not bounded in the lower or upper tail.

Kroll and Vogel (2002) used L-moments diagrams to examine 1505 gauged river sites in the United States, and recommended the LN3 distribution for describing low streamflow statistics at no intermittent (perennial) sites.

The General Extreme Value distribution (GEV) has been widely used in flood frequency and less in low-flow frequency analysis (Raynal, 1987):

$$
\begin{aligned}
& f(x)=(1 / \alpha)\left\{-[1-\beta(\omega-x) / \alpha]^{1 / \beta}\right\}^{\frac{1}{\beta}-1} \exp \\
& \left\{-[1-\beta(\omega-x) / \alpha]^{1 / \beta}\right\},
\end{aligned}
$$

If $\beta<0$ then $-\infty<x<\omega-\alpha / \beta$ and if $\beta>0$ then $\omega-\alpha / \beta<x<\infty$.

where $\alpha, \beta$ and $\omega$ are the scale, shape and location parameters.

Onoz and Bayazit (1999) examined the fit of various probability distributions to low flows at European rivers, and recommended the GEV distribution.

Pearson (1995) analyzed 1 day annual minimum stream flows at over 500 river sites in New Zealand, 
concluding that no single 2- or 3-parameter distribution provided a superior fit. Same conclusions were reported by Kroll and Vogel (2002). In order to achieve more flexibility in modeling low flows, two mixed distributions with four and five parameters are proposed in this paper.

\section{Mixed distributions}

The use of a mixture of probability distributions functions for modeling samples of data coming from two populations has been proposed long time ago (Mood et al., 1974):

$$
\operatorname{Pr}(X \leq x)=F(x)=p F_{1}(x)+(1-p) F_{2}(x)
$$

where $p$ is the proportion of $x$ in the mixture $(0<p<$ 1 ), and $F(x)$ is said to be a mixture of distributions.

Annual low flows are attributed to a continued depletion of basin water storage until the minimum level of discharge is attained.

The annual low flows of some rivers are related entirely to one process leading to water depletion (e.g. evaporation). In other basins, it may be caused by one process in some years, and another process in others (e.g. fall low flow due to evaporative loss, combined with spring low due to continental drainage without water replenishment from rain) (Waylen and Woo, 1987).

The events from each process form two separate annual minimum subpopulations can be combined to follow a distribution that reflects both sub-samples.

If the EV1 distribution is used in equation 5 , the mixed Gumbel distribution (EV1MIX) for the minima is

$$
\begin{aligned}
& F(x)_{\min }=p \exp ^{-\exp ^{-\left(\omega_{1}-x\right) / \alpha_{1}}+} \\
& (1-p) \exp ^{-\exp ^{-\left\langle\omega_{2}-x\right) / \alpha_{2}}}
\end{aligned}
$$

where $\omega_{1}, \alpha_{1}$ and $\omega_{2}, \alpha_{2}$ are the location and scale parameters for the first and second population.

The corresponding density function is

$$
\begin{aligned}
& f(x)_{\min }=\frac{p}{\alpha_{1}} \exp ^{-\exp ^{-\left(\omega_{7}-x\right) / \alpha 7}} \exp ^{-\left(\omega_{1}-x\right) / \alpha_{1}}+ \\
& \frac{(1-p)}{\alpha_{2}} \exp ^{-\exp ^{-\left(\omega_{2}-x\right) / \alpha_{2}}} \exp ^{-\left(\omega_{2}-x\right) / \alpha_{2}},
\end{aligned}
$$

Parameters can be computed by the maximum likelihood procedure:

$$
\ln L=\ln \prod_{i=1}^{n} f\left(x_{i} ; \omega_{1}, \alpha_{1} \omega_{2}, \alpha_{2}, p\right), \alpha_{i}>0
$$

where $\mathrm{L}$ is called the likelihood function and $\ln$ is the natural logarithm.

Given the complexity of the resulting likelihood function and the partial derivatives with respect to the parameters, the constrained multivariable Rosenbrock method (Kuester and Mize, 1973) was applied to obtain the estimators of the five parameters by the direct maximization of equation (8).

The Two Component Extreme Value distribution for the minima (TCEVMIN) is obtained by using the version for the maxima (Rossi et al., 1984) and the symmetry principle, Gumbel (1958):

$$
F(x)_{\min }=\exp \left(-\lambda_{1} \exp ^{x / \alpha_{1}}-\lambda_{2} \exp ^{x / \alpha_{2}}\right), \quad x \geq 0
$$

and

$$
\begin{aligned}
& f(x)_{\min }=\exp \left(-\lambda_{1} e^{x / \alpha_{1}}-\lambda_{2} e^{x / \alpha_{2}}\right) \\
& \left(\frac{\lambda_{1}}{\alpha_{1}} e^{x / \alpha_{1}}+\frac{\lambda_{2}}{\alpha_{2}} e^{x / \alpha_{2}}\right), \quad x \geq 0 .
\end{aligned}
$$

The parameters of the TCEVMIN distribution can be estimated from site-specific data set by the direct maximization of equation (11) by using the Rosenbrock method.

$$
\ln L=\ln \prod_{i=1}^{n} f\left(x_{i} ; \lambda_{1} \alpha_{1}, \lambda_{2}, \alpha_{2}\right)
$$

\section{Case study}

A region located in southern Mexico with 39 gauging stations was selected to apply the mixed distributions to lowest 1 day flows. For each station, mixed and standard distributions were fitted and the best one was chosen according to the criterion of minimum standard error of fit (SEF), as defined by Kite (1988):

$$
S E F_{j}=\left[\sum_{i=1}^{n}\left(g_{1}-h_{1}\right)^{2} /(n-q)\right]^{1 / 2},
$$

where $g_{i} ; i=1, \ldots, n$ are the recorded events, $h_{i} ; i=1, \ldots$, $n$ are the events computed from the probability distribution; $q$ is the number of parameters for each distribution $j$, and $n$ is the length of record.

Table 1 shows the available length of record and catchments area for each station in the region. Equations 
(1), (2), (3), (4), (8) and (11) were used in order to fit all samples in the region. The corresponding $\mathrm{SEF}_{j}$ were computed and the best distribution was selected according to its minimum value (table 2 ).

Table 1. Some characteristics of the stations whose annual minimum data are analyzed

\begin{tabular}{|c|c|c|c|c|c|}
\hline Station & $\begin{array}{l}\text { Lenght } \\
\text { (years) }\end{array}$ & area $\left(\mathrm{km}^{2}\right)$ & Station & $\begin{array}{l}\text { Lenght } \\
\text { (years) }\end{array}$ & area $\left(\mathrm{km}^{2}\right)$ \\
\hline Achotal & 18 & 2333 & la Estrella & 18 & 774 \\
\hline Amapa & 17 & 468 & La Junta & 18 & 11878 \\
\hline Amate & 14 & 102 & Las Prietas & 18 & 216 \\
\hline A. Cabadas & 18 & 125 & Matamba & 18 & 2143 \\
\hline Apoala & 18 & 341 & Mazatlan & 8 & 53 \\
\hline Axusco & 18 & 788 & Monte Rosa & 18 & 2870 \\
\hline Azueta & 18 & 4656 & Otapa & 9 & 64 \\
\hline Bellaco & 18 & 2917 & Papaloapan & 18 & 21236 \\
\hline Cabrito & 8 & 48 & Pumexcatan & 18 & 821 \\
\hline Camelpo & 13 & 2072 & Quiotepec & 18 & 4832 \\
\hline Canton & 18 & 14038 & S.J. Evangelista & 8 & 5651 \\
\hline Cuatotolapan & 18 & 7090 & Santo Domingo & 17 & 12681 \\
\hline Cuichapa & 18 & 1732 & Suchicatlan & 13 & 93 \\
\hline Culebra & 13 & 138 & Teopixca & 12 & 27 \\
\hline Dominguillo & 18 & 695 & Tepelmeme & 18 & 167 \\
\hline Hamaca & 10 & 30 & Tomellin & 18 & 780 \\
\hline Inguirjo & 10 & 21 & Tuxtepec & 18 & 15719 \\
\hline Jacatepec & 18 & 1117 & Xiquila & 18 & 1078 \\
\hline Lauchapan & 18 & 1478 & Zapote & 18 & 633 \\
\hline La Angostura & 18 & 6574 & & & \\
\hline
\end{tabular}

Table 2. Standard error of fit in $\mathrm{m}^{3} / \mathrm{s}$ and selected distribution for each gauging station

\begin{tabular}{ccccccccc}
\hline Station & LN3 & EV1 & GEV & W3 & EV1MIX & TCEVMIN & Desicion \\
\hline Achotal & 3.439 & 1.478 & 0.611 & 1.149 & 0.821 & 0.495 & TCEVMIN \\
Amapa & 0.258 & 0.178 & 0.040 & 0.018 & 0.058 & 0.087 & W3 \\
Amate & 0.086 & 0.087 & 0.025 & 0.037 & 0.038 & 0.039 & GEV \\
A. Cabadas & 2.876 & 0.663 & 0.310 & 0.482 & 0.270 & 0.323 & EV1MIX \\
Apoala & 0.040 & 0.030 & 0.010 & 0.018 & 0.012 & 0.008 & TCEVMIN \\
Axusco & 0.141 & 0.008 & 0.002 & 0.003 & 0.003 & 0.003 & GEV \\
Azueta & 6.710 & 2.514 & 1.671 & 2.622 & 1.835 & 1.743 & GEV \\
\hline
\end{tabular}


C.A. Escalante-Sandoval

Table 2. Standard error of fit in $\mathrm{m}^{3} / \mathrm{s}$ and selected distribution for each gauging station (...continuation)

\begin{tabular}{|c|c|c|c|c|c|c|c|}
\hline Station & LN3 & EV1 & GEV & W3 & EV1MIX & TCEVMIN & Desicion \\
\hline Bellaco & 4.697 & 2.373 & 0.899 & 1.986 & 1.143 & 0.831 & TCEVMIN \\
\hline Cabrito & 1.595 & 0.046 & 0.011 & 0.019 & 0.017 & 0.015 & TCEVMIN \\
\hline Camelpo & 0.160 & 0.016 & 0.007 & 0.009 & 0.012 & 0.008 & GEV \\
\hline Canton & 2.123 & 1.076 & 0.957 & 1.435 & 0.585 & 1.645 & EV1MIX \\
\hline Cuatotolapan & 7.522 & 2.227 & 1.105 & 2.166 & 1.102 & 1.188 & EV1MIX \\
\hline Cuichapa & 4.469 & 1.142 & 0.607 & 1.011 & 0.422 & 0.541 & EV1MIX \\
\hline Culebra & 0.006 & 0.005 & 0.002 & 0.003 & 0.004 & 0.006 & GEV \\
\hline Dominguillo & 0.197 & 0.092 & 0.019 & 0.039 & 0.027 & 0.016 & TCEVMIN \\
\hline Hamaca & 0.001 & 0.001 & 0.001 & 0.001 & 0.001 & 0.002 & W3 \\
\hline Inguirjo & 0.002 & 0.002 & 0.001 & 0.001 & 0.001 & 0.002 & W3 \\
\hline Jacatepec & 4.662 & 2.525 & 1.096 & 1.895 & 0.781 & 1.119 & EV1MIX \\
\hline Lauchapan & 9.033 & 1.631 & 0.929 & 1.576 & 0.639 & 1.094 & EV1MIX \\
\hline La Angostura & 0.244 & 0.216 & 0.086 & 0.166 & 0.099 & 0.087 & GEV \\
\hline La Estrella & 5.200 & 1.971 & 0.746 & 1.308 & 0.696 & 0.756 & EV1MIX \\
\hline La Junta & 8.098 & 0.430 & 0.315 & 0.454 & 0.468 & 0.334 & GEV \\
\hline Las Prietas & 0.336 & 0.126 & 0.025 & 0.046 & 0.049 & 0.057 & GEV \\
\hline Matamba & 5.353 & 0.350 & 0.235 & 0.353 & 0.122 & 0.278 & EV1MIX \\
\hline Mazatlan & 0.086 & 0.053 & 0.020 & 0.026 & 0.033 & 0.028 & GEV \\
\hline Monte Rosa & 2.558 & 1.009 & 0.580 & 0.969 & 0.656 & 0.664 & GEV \\
\hline Otapa & 0.489 & 0.023 & 0.012 & 0.019 & 0.036 & 0.030 & GEV \\
\hline Papaloapan & 23.31 & 10.84 & 9.253 & 17.16 & 9.737 & 14.47 & GEV \\
\hline Pumexcatan & 2.164 & 0.443 & 0.326 & 0.489 & 0.182 & 0.399 & EV1MIX \\
\hline Quiotepec & 3.295 & 0.271 & 0.192 & 0.324 & 0.222 & 0.224 & GEV \\
\hline S.J. Evangelista & 20.30 & 10.17 & 7.120 & 8.314 & 9.116 & 9.324 & GEV \\
\hline Santo Domingo & 1.151 & 0.882 & 0.412 & 0.778 & 0.372 & 0.498 & EV1MIX \\
\hline Suchicatlan & 0.008 & 0.004 & 0.001 & 0.002 & 0.004 & 0.005 & GEV \\
\hline Teopixca & 0.071 & 0.124 & 0.057 & 0.072 & 0.075 & 0.070 & GEV \\
\hline Tepelmeme & 0.012 & 0.016 & 0.006 & 0.008 & 0.009 & 0.007 & GEV \\
\hline Tomellin & 0.012 & 0.011 & 0.004 & 0.006 & 0.008 & 0.005 & GEV \\
\hline Tuxtepec & 24.26 & 35.96 & 16.88 & 22.54 & 21.86 & 22.21 & GEV \\
\hline Xiquila & 0.130 & 0.117 & 0.049 & 0.091 & 0.046 & 0.062 & EV1MIX \\
\hline Zapote & 1.647 & 1.336 & 0.695 & 1.057 & 0.251 & 0.758 & EV1MIX \\
\hline
\end{tabular}


In 2003, the Comision Federal de Electricidad proposed the construction of La Parota Dam in the southern State of Guerrero, Mexico. The $180 \mathrm{~m}$ and 765-megawatt dam located in the Papagayo River watershed would flood close to 17,000 hectares of land. Communities around the site of the project are concerned because of the expected changes to the river ecosystem downstream of the dam. Major losses in fisheries could occur all the way downstream of the dam until the river's delta at the Pacific Ocean.

In order to do an integral assessment of the environmental impact associated with the hydroelectric project, it is necessary to account with an estimate of the possible ecological flow of the river. According to the one of the aquatic life criteria proposed by the United States Environmental Protection Agency (EPA, 2006), the hydrologically-based design flow ${ }_{7} \mathrm{Q}_{10}$ is obtained by using the lowest 7-day average flows computed through the gauged data at station La Parota (table 3). The EV1, GEV, W3, and mixed distributions were used to fit the sample. The corresponding $\mathrm{SEF}_{\mathrm{j}}$ and the design events for different return periods are shown in table 4. By considering the criterion of the minimum standard error of fit and from an hydrological point of view, the EV1MIX distribution was selected, and the low flow ${ }_{7} \mathrm{Q}_{10}=10.4 \mathrm{~m}^{3} / \mathrm{s}$ would be the minimum condition to maintain the water quality and the aquatic life downstream of the dam.

When a short record is used, there is an increased risk that the low-flow estimate will not provide adequate protection of designated uses. One way to reduce the bias or uncertainty in the low-flow estimate is to use a regional data set with observations from several sites. Mixed distributions can be easily used to obtain

Table 3. The lowest 7 day average flows in $\mathrm{m}^{3} / \mathrm{s}$ at gauging station La Parota

\begin{tabular}{cccccccc}
\hline year & $7 \mathrm{Q}(\mathrm{m} 3 / \mathrm{s})$ & year & $7 \mathrm{Q}(\mathrm{m} 3 / \mathrm{s})$ & year & $7 \mathrm{Q}(\mathrm{m} 3 / \mathrm{s})$ & year & $7 \mathrm{Q}(\mathrm{m} 3 / \mathrm{s})$ \\
\hline 1963 & 19.8 & 1973 & 15.3 & 1983 & 13.1 & 1993 & 18.7 \\
1964 & 15.1 & 1974 & 19.3 & 1984 & 14.2 & 1994 & 15.0 \\
1965 & 0.3 & 1975 & 19.1 & 1985 & 17.1 & 1995 & 15.2 \\
1966 & 19.1 & 1976 & 13.0 & 1986 & 15.8 & 1996 & 9.8 \\
1967 & 19.0 & 1977 & 16.4 & 1987 & 3.2 & 1997 & 21.1 \\
1968 & 14.4 & 1978 & 15.3 & 1988 & 13.4 & 1998 & 15.7 \\
1969 & 17.5 & 1979 & 22.3 & 1989 & 17.7 & 1999 & 11.9 \\
1970 & 15.4 & 1980 & 17.4 & 1990 & 21.5 & & \\
1971 & 18.9 & 1981 & 16.9 & 1991 & 9.8 & & \\
1972 & 16.5 & 1982 & 23.2 & 1992 & 21.1 & & \\
\hline
\end{tabular}

Table 4. At-site design events $7 Q$ in $\mathrm{m}^{3} / \mathrm{s}$ for different return periods and the SEF for the hydroelectric project La Parota

\begin{tabular}{cccccc}
\hline Return period & \multicolumn{5}{c}{ Distribution } \\
\hline T (years) & EV1 & GEV & W3 & EV1MIX & TCEVMIN \\
2 & 16.6 & 15.0 & 14.9 & 16.5 & 15.5 \\
5 & 12.7 & 12.1 & 11.0 & 12.8 & 10.4 \\
10 & 10.0 & 10.9 & 9.1 & 10.4 & 8.3 \\
20 & 7.6 & 10.0 & 7.6 & 6.1 & 6.7 \\
50 & 4.3 & 9.2 & 6.0 & 2.9 & 5.0 \\
100 & 1.9 & 8.7 & 5.1 & 1.4 & 4.0 \\
SEF $_{\mathrm{j}}$ & 1.5 & 2.4 & 2.0 & 3.8 \\
\hline
\end{tabular}

